\title{
MAKNA TOLERANSI PERSPEKTIF TAFSIR AL-BURHAN DI DALAM SURAT AL-KAFIRUN
}

\author{
Ahmad Murtaza MZ \\ Prodi Ilmu Al-Qur'an dan Tafsir, Fakultas Ushuluddin dan Pemikiran Islam, UIN Sunan \\ Kalijaga \\ ahmadmurtaza378@gmail.com
}

Muhammad Mulkan

Prodi Ilmu Agama Islam, Fakultas pascasarjana, UIN Walisongo

muhammadmulkan29@gmail.com

\begin{abstract}
Abstrak
Paham toleransi secara bertahap mulai terkikis oleh paham-paham intoleran yang menggerogoti nilai-nilai toleransi yang sudah ditanamkan sejak dahulu. Penelitian ini merupakan penelitian pustaka yang bertujuan untuk menangkap paham toleransi perspektif mufasir nusantara yang terdapat dalam Surat Al-Kafirun dalam Tafsir Al-Burhan karya Abdul Karim Amrullah. Penelitian ini menemukan bahwa seruan untuk saling bertoleransi antar umat agama dalam ajaran Agama Islam sudah dipraktikkan dari zaman ke zaman. Adanya individu yang melakukan tindak kekerasan atau aksi terorisme bukanlah bagian dari ajaran yang telah tertuang dalam Al-Qur'an, karena anjuran menebar kasih sayang dan cinta sesama manusia merupakan titik tekan dalam ajaran Islam yang menjunjung tinggi nilai-nilai humanisme dan perdamaian. Sehingga toleransi antar umat beragama secara serius dipraktikkan dalam kehidupan sehari-hari dalam bermasyarakat yang beragam.
\end{abstract}

Kata Kunci: toleransi, Al-burhan, interpretasi

\begin{abstract}
The notion of tolerance is gradually being eroded by intolerant ideas that undermine the values of tolerance that have been instilled long ago. This research is a literature study that aims to capture the understanding of the tolerance of the archipelago's mufasir perspective contained in Surat Al-Kafirun in Tafsir Al-Burhan by Abdul Karim Amrullah. This study found that the call for mutual tolerance between religious communities in the teachings of Islam has been practiced from time to time. The existence of individuals who commit acts of violence or acts of terrorism is not part of the teachings contained in the Qur'an, because the suggestion to spread compassion and love for fellow human beings is a pressure point in Islamic teachings that uphold the values of humanism and peace. So that inter-religious tolerance is seriously practiced in everyday life in a diverse society.
\end{abstract}

Keywords: tolerance, Al-Burhan, interpretation

\section{PENDAHULUAN}

Sikap intoleransi yang mengatasnamakan agama sebagai dalih kebolehan atas praktik tersebut semakin masif terdengar beberapa tahun terakhir. Konflik antar agama yang terjadi menimbulkan rasa curiga, cemas dan tidak saling percaya bagi tiap pemeluk agama. Anjuran saling menghormati, saling menyayangi dan menebarkan perdamaian antar umat beragama merupakan bagian dari ajaran Agama 
Islam, sedangkan dalam praktiknya dibutuhkan kajian yang komprehensif karena sikap toleran dalam penerapannya akan membuahkan keharmonisan serta ketenteraman bagi tiap pemeluk agama. ${ }^{1}$ Dewasa kini, Agama Islam menjadi perbincangan hangat oleh Kaum Zionis dan Barat yang mempropagandakan Islam sebagai agama yang menganut paham intoleran dan anti keberagaman. ${ }^{2}$

Perbedaan merupakan sesuatu yang tidak bisa dihindari karena merupakan bagian dari sunnatullah. Adapun toleransi yang masih menjadi kontroversi serta mendapat kritik dari beberapa kelompok dari aspek prinsip serta penerapannya baik dari kalangan latitudinarian (kebebasan beragama) dan tradisional. ${ }^{3}$ Sejatinya, sikap intoleransi yang dipropagandakan oleh Kaum Zionis dan Barat maupun kritik yang dikemukakan atas perbedaan prinsip-prinsip toleransi secara eksplisit sudah terjawab oleh Al-Quran secara gamblang. Sehingga, umat Islam berupaya secara dinamis untuk mendalami rancangan toleransi yang diajarkan oleh Islam. Upaya ini bertujuan untuk menepis segala utopia yang ditujukan kepada Islam. ${ }^{4}$ Islam menerangkan praktik dan anjuran bertoleransi antar umat beragama yang tertuang dalam Surah Al-Kafirun. Surah tersebut mengajarkan Umat Islam bagaimana cara bersikap dan tata cara berinteraksi sosial serta bertoleransi antar pemeluk agama. Surah Al-Kafirun melalui terjemahan secara harfiah telah mengandung signifikansi humanisme, keharmonisan, keselarasan kepada penganut agama lainnya. Hal ini membuktikan bahwasanya sikap toleransi dalam praktiknya bagi Islam bukanlah sesuatu yang asing lagi.

Kajian mengenai toleransi sebagai sebuah praktik keagamaan merupakan saru kajian yang telah banyak dikaji oleh para peneliti. Sekurang-kurangnya ditemukan dua kecenderungan dalam pembahasan ini. Pertama, kajian yang mengungkapkan makna toleransi dalam tiap-tiap ayat dalam al-Qur'an. ${ }^{5}$ Kedua, kajian ayat-ayat toleransi menurut pandangan para tokoh-tokoh tafsir serta menjelaskan ulang dalam konteks Keindonesiaan. ${ }^{6}$ Adapun kajian mengenai toleransi antar umat beragama pada suasana masa penjajahan Belanda dan Jepang oleh Abdul Karim Amrullah yang merupakan ulama tafsir dari Sumatera Barat yang tergolong sebagai ulama pembaharu saat itu merupakan kajian yang terlewat dari perhatian para peneliti. Pada poin ini akhirnya penelitian dalam artikel ini menjadi satu hal yang penting untuk dilakukan.

${ }^{1}$ Ahmad Zainul Arifin, Khairudin dan Moh. Rifa'I, “Ayat Toleransi Dalam AlQur'an Perspektif Tafsir Al-Kabir (MafaatihulGhaib)", An-Nuha: Jurnal Kajian Islam, Pendidikan, Budaya dan Sosial. Vol. 6, No. 2, (2019), h.196.

${ }^{2}$ Muhammad Yasir, "Makna Toleransi Dalam Al-Qur'an”, Jurnal Ushuluddin, Vol. 22, No. 2, (2014), h.177.

3 Abu Bakar, "Konsep Toleransi dan Kebebasan Beragama", Toleransi; Media Komunikasi Umat Beragama, Vol.7, No.2, (2015), h.123.

${ }^{4}$ Muhammad Yasir, "Makna Toleransi Dalam Al-Qur'an”, h. 170.

${ }^{5}$ Muhammad Yasir, Makna Toleransi Dalam Al-Qur'an, Jurnal Ushuluddin, Vol. 22, No. 2, (2014).

6 Ahmad Zainul Arifin, Khairudin dan Moh. Rifa'I, Ayat Toleransi Dalam AlQur'an Perspektif Tafsir Al-Kabir (MafaatihulGhaib), An-Nuha: Jurnal Kajian Islam, Pendidikan, Budaya dan Sosial. Vol. 6, No. 2, (2019). 
Sejumlah literatur yang telah disebutkan sebelumnya sebagai landasan agar penelitian ini dapat melengkapi ruang kosong yang belum di teliti sebelumnya. Sejalan dengan itu, peneliti mengajukan beberapa pertanyaan berikut. Pertama, bagaimana interpretasi mengenai toleransi dalam surah Al-Kafirun dalam Tafsir AlBurhan?. Kedua, bagaimana pandangan Abdul Karim Amrullah tentang toleransi?. Kedua pertanyaan yang diajukan di aras menggambarkan pemahaman yang begitu komprehensif tentang toleransi oleh Abdul Karim Amrullah dalam tafsirnya sehingga membentuk pemahaman primordial dalam ajaran Islam.

Penelitian ini memiliki asumsi bahwa pertama, tafsiran yang dijadikan rujukan oleh Abdul Karim Amrullah begitu kompleks dan moderat serta isi penafsirannya menyajikan begitu banyak pandangan ulama tafsir sampai-sampai memberikan pandangan yang beragam mengenai toleransi. Kedua, Abdul Karim Amrullah memiliki latar belakang pendidikan Islam yang begitu menawan serta diajari oleh para ulama-ulama azmat hingga membentuk pola pikir ekstensif dari diri Abdul Karim Amrullah.

\section{TINJAUAN PUSTAKA}

A. Toleransi Beragama Dalam Islam

Toleransi (tasamukh) secara etimologi memiliki arti sebagai sikap membairkan lapang dada. ${ }^{7}$ Adapun toleransi secra terminologi ialah sikap untuk membiarkan setiap individu untuk melakukan sesuatu hal sesuai kepentingannya. Jika dalam konteks keagamaan ialah memepersilahkan setiap individu yang beragama untuk menjalani setiap peribadatan dalam agama masing-masing dan tidak boleh adanya gangguan-gangguan dari luar. ${ }^{8}$

Said Agil al-Munawwar mengkalsifikasikan toleransi kepada dua jenis, yaitu toleransi statis dan toleransi dinamis. Pertama, tolernasi statis adalah toleransi yang mengalami stagnasi dan hanya sebatas teoritis saja. Kedua, toleransi dinamis yang aktif, adanya kerjasama antar umat beragama serta menjunjung tinggi akan kepentingan bersama. Dari dua klasifikasi yang telah dikemukakan bahwasanya toleransi tidak sebatas teoritis saja, melainkan membutuhkan kerja sama setiap individual yang beragama sehingga kebersamaan dan kerjasama merupakan sebuah keniscayaan.

Islam memberikan definisi toleransi melalui sebuah hadis yang diriwayatkan oleh Abu Hurairah berikut.



${ }^{7}$ M. Maulana Mas'udi, Toleransi Dalam Islam (Antara Ideal Dan Realita), AlHikmah: Jurnal Studi Agama-Agama, Vol. 5, No. 1, (2019), h. 19.

${ }^{8}$ M. Thoriqul Huda dan Luthfiah, Toleransi dalam Kitab Tafsir Taisir al-Karim alRahman fi Tafsir al-Kalam al-Mannan, Qolamuna: Jurnal Studi Islam, Vol. 4, No. 1, (2018), h. 252.

${ }^{9}$ Dewi Anggraeni dan Siti Suhartinah, Toleransi Antar Umat Beragama Perspektif KH. Ali Mustafa Yaqub, Jurnal Studi Al-Qur'an: Membangun Tradisi Berpikir Qur'an, Vol. 14, No. 1, (2018), h. 66. 
Dari Abu Hurairah RA, Rasulullah SAW bersabda: "Perumpamaankuku dan perumpamaan para nabi terdahulu, yaitu seperti seseorang yang membangun rumah lalu menyempurnakannya dan memperindahnya kecuali sebuah batu di bagian pojok rumah. Kemudian orang-orang yang mengelilingi dan mengagumi rumah tersebut, mereka bertanya, kenapa batu ini tidak diletakkan? Rasulullah SAW menjawab, "saya adalah batunya dan saya adalah penutup para nabi." (HR. Bukhori). ${ }^{10}$

Hadis tersebut dapat dijadikan sebuah pondasi dalam membangun toleransi antar umat beragama yang menjadi kata kunci dalam hadis tersebut ialah bagaimana cara rasulullah mengibaratkan ajaran-ajaran agama oleh nabi-nabi terdahulu sebagai rumah yang sudah menjadi bangunan kokoh dan megah. Sedangkan ajaran-ajaran yang dibawakan oleh Nabi Muhammad bukanlah untuk merobohkan ajaran-ajaran terdahulu melainkan menjadi pelengkap dan penyempurna teradap ajaran-ajaran sebelumnya.sehingga intisari dari hadis diatas ialah Islam menjunjung tinggi toleransi antar umat beragama. ${ }^{11}$

Contoh ayat al-Qur'an yang mendiskusikan tentang toleransi, Allah berfirman dalam Q.S. Al-Baqarah/2:256.

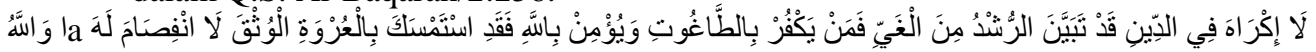
سَمِيعِ عَلِيمُ (256)

Artinya: "Tidak ada paksaan untuk (memasuki) agama (Islam); sesungguhnya telah jelas jalan sesungguhnya telah jelas jalan yang benar daripada jalan yang sesat. Karena itu barangsiapa yang ingkar kepada Thaghut dan beriman kepada Allah, maka sesungguhnya ia telah berpegang kepada buhul tali yang amat kuat yang tidak akan putus dan Allah maha mendengar lagi maha mengetahui.",12

Ahmad Hassan memberikan komentar mengenai tidak ada paksaan dalam beragama yang dimaksudkan dalam ayat ini ialah seseorang tidak boleh sekali-kali dipaksa memeluk suatu agama dan tidak dapat dipaksa dalam hal keimanan. ${ }^{13}$ Sejalan dengan Ahmad Hassan, Quraish Shihab tidak ada paksaan dimaksud ialah tidak ada paksaan dalam menganut akidah. ${ }^{14}$

Sebuah penelitian yang dilakukan oleh Muhammad Yasir telah mengklasifikasi toleransi dalam Al-Qur'an menjadi 3, yaitu: ${ }^{15}$

1. Toleransi dalam keyakinan dan menjalankan ibadah, berdasarkan ayat al-quran dalam Surat Ali-Imran:19, Al-Kafirun:1-6, An-Najm:23.

2. Toleransi hidup berdampingan dengan agama lain, merujuk pada ayat al-qur'an Surat Al-Baqoroh:256 Dan Al-Ghosiyyah:21-22.

10 Muhammad bin Isma'ill, Shahih Al- Bukhori (Cet. I; t.t, Dar Tuk An-Najah, 1422), h.186.

11 Ahmad Zainul Arifin, Khairudin dan Moh. Rifa'I, “Ayat Toleransi Dalam AlQur'an Perspektif Tafsir Al-Kabir (MafaatihulGhaib)", h.196.

12 Al-Qur'an Surah Al-Baqarah/2:256

13 Ahmad Hassan, Al-Furqon Tafsir Qur'an, (Jakarta: Universitas Al-Azhar Indonesia, 2010), h.73.

14 M. Quraish Shihab, Tafsir al-Misbah, (Cet: I, Tanggerang: Lentera Hati, 2002), h. 546 .

15 Muhammad Yasir, Makna Toleransi Dalam A-Qur'an, h. 177. 
3. Toleransi dalam hubungan antar bermasyarakat, belandaskan ayat al-qur'an Surat Al-Maidah:2 Dan Al-Mumtahanah:8-9.

Berdasarkan penelitian di atas dapat ditemukan sebuah fakta jika Islam telah mengajarkan toleransi kepada tiap pemeluknya, bahkan telah dipraktikkan secara langsung oleh Nabi saw., melalui wahyu Al-Qur'ann sebagai penegasan dalam penerapannya di kehidupan bermasyarakat.

\section{B. Surat Al-Kafirun}

Dalam beberap kitab tafsir, surat al-Kafirun merupakan sebuah penegasan mengenai akidah ajaran Islam. Ahmad Hasan menegaskan bahwasanya surat Al-Kafirun berisikan penjelasan tentang prinsip tidak adanya toleransi dalam hal keimanan dan ibadah kepada Allah. ${ }^{16}$ Berkenaan mengenai dimana surat ini diturunkan adanya perdebatan, di dalam Tafsir Fathul Qadir surat ini diturunkan di Mekah menurut Ibnu Mas'ud, Al Hasan, Ikrimah, dan diturunkan di Madinah menurut Qatadah dan AdhDhahhak. ${ }^{17}$ Sedangkan menurut Buya Hamka di dalam tafsirnya menjelaskan bahwasanya surat ini tergolong surat makiyyah karena tujuan dalam ayat ini ialah kaum musrikin, yang kafir, yang artinya tidak menerima seruan dari Nabi kepada mereka. ${ }^{18}$

Berkenaan dengan asbab nuzul surat ini sebagaimana yang dicantumkan oleh Quraish Shihab dalam tafsirnya, bahawaasnya ada beberapa kaum musyrikin dari Mekkah seperti al-Walid Ibn al-Mughirah, Aswad Ibn Abdul Muthalib, Umayah Ibn Khalaf, mendatangi nabi untuk berengosiasi perihal kepercayaan. Mereka mengusulkan agar Nabi Muhammad beserta pengikutnya menyembah apa yang mereka sembah begitu pula sebaliknya. Dialog ini ditolak oleh Rasul, karena bagi Rasul ini merupakan sesuatu yang tidak logis untuk menyatukan agama-agama, karena setiap agama memiliki ajaran pokok yang berbeda-beda. ${ }^{19}$

Sedangkan di dalam tafsir Thabari bahwasanya surat in turun ketika perwakilan dari Quraisy Al-Walid bin Al-Mughirah, Al -Ash bin Wa'il, Al-Aswad bin AlMuththalib dan Umalyah bin Khalaf berjumpa dengan Nabi saw., lalu mereka berkata, "Hai Muhammad, mari, kami akan menyembah apa yang engkau sembah, dan engkau juga menyembah apa yang kami sembah, kami akan menyertakamu dalam semua urusan kami. Jika apa yang engkau bawa itu lebih baik daripada apa yang ada pada kami, maka kami telah turut serta di dalamnya dan mengarnbil bagian kami darinya. Begitu juga bila apa yang pada kami lebih baik dari pada yang ada padamu, berarti engkau telah turut serta dalam perkara kami dan mengambil bagianmu darinya." Lalu Allah menurunkan surat ini. ${ }^{20}$

Hasbi as-Siddieqi memberikan komentarnya terhadap surat al-Kafirun bahwasanya ma'bud (tuhan yang disembah) oleh Muhammad dan kaum Muslimin tidaklah serupa atau tidak sama sebagaimana ma'bud atau sesembahan orang musyrik. Begitupula ritual peribadatan yang dilakukan oleh Muhammad saw., dan umatnya yang

${ }^{16}$ Ahmad Hassan, Al-Furqon Tafsir Qur'an, h. 1094.

17 Imam Asy-Syaukani, Tafsir Fathul Qadir", (Jakarta Selatan: Pustaka Azzam, 2009), h. 602.

18 Hamka, Tafsir Al-Azhar (Singapura: Pustaka Nasioanal PTE LTD Singapura, 1999), hal.8131.

${ }^{19}$ Quraish Shihab, Tafsir al-Misbah, h. 574.

20 Abu Ja'far Muhammad bin Jarir Ath-Thabari, Tafsir Ath-Thabari, (Jakarta Selatan: Pustaka Azzam, 2007), h. 1049. 
berlandaskan kepada keikhlasan dan ketulusan hati, serta tidak berniat sedikitpun untuk mempersekutukan Allah karena hal ini yang menjadi pembeda dari ibadah-ibadah orangorang musyrik. $^{21}$

\section{MISINTERPRETASI TERHADAP TOLERANSI}

Pemaknaan mengenai toleransi haruslah dipahami secara benar, agar tidak terjadi kekeliruan yang berimplikasi terhadap keimanan atau akidah setiap pemeluk agama, maka dalam hal ini butuh kajian kritis terhadap hal tersebut. Dalam Islam tidak ada pelarangan kepada umatnya untuk menjaling relasi ataupun hubungan kepada nonmuslim, namun hanya sebatas urusan duniawi saja. ${ }^{22}$

Memperjuangkan akan pemahaman yang benar yang berkenaan tentang kerukunan hidup antar umat atau pemeluk agama lain di dalam masyarakat harus dilakukan tanpa mengorbankan akidah masing-masing pemeluk agama. ${ }^{23}$ Standarisasi mengenai toleransi dalam Islam ialah ketika menghadapi segala tuduhan yang besifat merendahkan bahkan menghina, tidaklah perlu untuk menaggapinya, karena memaafkan menjadi prioritas yang utama, namun jika tetap ingin memberikan tanggapan, maka tanggapan tersebut tidaklah boleh melakukan tindakan yang berlebihan. ${ }^{24}$

\section{Metodologi Penelitian}

Sebagaimana fokus terhadap penelitian, dan subjek yang diteliti, penelitian ini adalah riset pustaka (library research), yaitu data-data atau bahan-bahan yang diperlukan dalam menyelesaikan penelitain tersebut berasal dari perpustakaan baik berupa buku, ensiklopedi, dokumen, majalah, dan lain sebagainya. Adapun yang menjadi sumber primernya ialah Tafsir Al-Burhan karya Abdul Karim Amrullah dan buku-buku yang yang membahas toleransi antar umat beragama sedangkan yang menjadi sumber sekunder dalam penelitian ini adalah literatur yang bersumber dari jurnal artikel ilmah, skirpsi, tesis ataupun sumber-sumber yang berasal dari dunia maya.

Adapun metode yang digunakan dalam penelitian adalah analisis deskriptif, dimana akan menggambarkan dan menjelaskan fakta-fakta yang berasal dari sebuah kejadian. Penulis berupaya menjelaksan tentang pemikiran Abdul Karim Amrullah mengenai sikap toleransi antar umat beragama.

Metode analisis yang penulis gunakan dalam tulisan ini adalah menggunakan metode interpretif. Metode cocok digunakan untuk memperlihatkan makna toleransi yang ditunjukkan dalam surat Al-Kafirun. Subjek penelitian ini adalah Abdul Karim Amrullah, sedangkan objek penelitian adalah surat al- Kafirun di dalam Tafsir Al-burhan.

\section{RESULT}

\section{Biografi Abdul Kariam Amrullah}

Abdul Karim Amrullah lahir pada tanggal 10 Februari 1879 bertepatan 17 Safar 1296 H di Maninjau, Sumatera Barat. Ia lebih akrab dipanggil "Haji Rasul" atau "Inyak Dr." beliau adalah anak pertama seorang ulama ternama, Syekh Muhammad Amrullah

21 Muhammad Hasbi ash-Shiddieqy, Tafsir al-Qur'anul Majid An-Nur, (Semarang: Pustka Rizki Putra, 2000), h.4717.

${ }^{22}$ M. Wahid Nur Tualeka, Kajian Kritis Tentang Toleransi Beragama Dalam Islam, AL-Hikmah: Jurnal Studi Agama-Agama, Vol. 2, No. 2, (2016), h.8

23 Salma Mursyid, Konsep Toleransi (Al-Samahah) Antar Umat Beragama Perspektif Islam, Jurnal Aqlam Journal of Islam and Plurality, Vol. 2, No.1 (2016), h.50.

${ }^{24}$ Abu Bakar, Konsep Toleransi dan Kebebasan Beragama, Toleransi, h. 130. 
yang bergelar "Tuanku Kisai" 25 beliau wafat pada tahun 1325 pada usia 79 tahun. Ibunya bernama Tarwasa merupakan istri ketiga dari Syekh Amrullah, ibunya meninggal setahun sebelum meninggal dari pada beliau yakni pada tahun $1943 .^{26}$

Haji Rasul berasal dari keturunan ulama yang terpandang di negerinya dan tokoh yang berpengaruh pada zamannya. Kakeknya Syekh Abdullah Arief dari garis keterunan ibu, Siti Saerah yang dikenal sebagai Tuanku Pariaman, Tuanku Nan Tuodi Koto Tuo IV salah seorang ulama yang menyebarkan Islam di Minangkabau dan dikenal sebagai salah seorang pahlawan yang gigih melawan Belanda dalam perang Paderi yang bertugas mempertahankan daerah IV Koto Lawang dan Andalas. ${ }^{27}$

Pendidikan agama sudah diajarkan kepada Abdul Karim Amrullah sejak kecil, pada usianya 7 tahun ia sudah disuruh untuk puasa dan sholat oleh kedua orangtunya. Pada usia 10 tahun haji rosul sudah dibawa oleh pamannya yang bernama H. Abdul Samad ke Tarusan, Painan. Disana ia belajar al-Qur'an kepada Tuanku Haji Hud dan Tuanku Pakih Samanun sampai selesai. Kemudian, Abdul Karim kembali ke Sungai Batang guna mempelajari menulis huruf Arab kepada Adam anak Tuanku Said. Saat usia 13 tahun mulai belajar Nahwu dan Shorof kepada ayahnya. Kemudian, ayahnya mengirimnya ke Sungai Rotan Pariaman, dua tahun lamanya untuk mempelajari kitab Minhajut Tholibin karangan Imam Nawawi dan Tafsir Jalalain kepada Tuanku Sultan Muhammad Yusuf yang merupakan murid ayahnya. ${ }^{28}$

Selesai dari Sungai Rotan, Abdul Karim Amrullah yang saat itu berusia 16 tahun HajRasul berangkat ke Mekkah, karena ayahnya memiliki keinginan agar anaknya bisa menjadi seorang yang paham agama dan meneruskan peran nenek moyangnya dalam mempelajari ilmu agama. Apalagi di Mekkah saat itu sangat terkenal teman mengaji ayahnya yaitu Syekh Chotib al-Minangkabawai.

Tahun 1312 H (1895) Abdul Karim Amrullah belajar ke Mekkah. Di Mekkah Abdul Karim Amrullah belajar kepada Syekh Khotib al-Minangkabawi. Selama 7 tahun belajar di Mekkah, Abdul Karim Amrullah memiliki teman yang seperti dirinya yang suatu waktu menjadi ulama sepertinya. Teman-temannya antara lain, Syekh Muhammad Jamil Jambek yang sudah terlebih dahulu belajar darinya. Syekh Taher Jalaluddin yang merupakan ahli falak yang terkenal.

Abdul Karim Amrullah tidak hanya belajar kepada Syekh Ahmad Khotib AlMinangkawai, namun belajar pula kepada beberapa guru seperti, Syekh Abdullah Jamidin, Syekh Usman Serawak, Syekh Umar Bajened, Syekh Saleh Bafadal, Syekh Hamid Jeddah, Syekh Sa'id Jaman dan beajar kepada Yusuf Nabhani yang merupakan pengarang kitab Al-Anwaarul Muhammadiyah. ${ }^{29}$

25 Muhammad Amrulah bin Abdullah Saleh, atau bin Saerah binti Abdullah Arif, Tuanku nan Tuo,dilahirkan di Sungai Batang Maninjau pada tahun $1256 \mathrm{H}$, bertepatan dengan tahun 1839, yakni dua tahun sesudah jatuhnya benteng Bonjol ke tangan Belanda. Kisai'seorang guru Tarekat Naqsyabandiah yang istiqomah dalam mengikuti Mazhab Syafi'i di Maninjau.

${ }^{26}$ Hamka, Ayahku, Riwayat Hidup Dr. H. Abdul Karim Amarullah Dan Perjuangan Kaum Agama di Sumatera (Djakarta: Widjaya,1958), h. 45.

${ }_{27}$ Novita Siswayanti, Haji Abdul Karim Amrullah Ulama Pembaharu Islam di Minangkabau, Dialog jurnal penlitian dan kajian keagamaan, vol. 39 No.1 (2016), h. 33-42.

${ }^{28}$ Hamka, Ayahku, h.45-46

${ }^{29}$ Hamka, Ayahku, h.45-46 
Aktif dalam bidang tulis menulis Abdul Karim Amrullah memiliki sejumlah karya yang di bagi menjadi dua, yakni sebelum berangkat ke Mesir dan Sesudah dari Mesir, antara lain: 'Amdatul Anam fi Ilmil Kalam (sifat 20) 1908, Qathi'u riqabil Mulhidin (membantah tarikat Naqsabndiah) 1910, Syamsul Hidayah (Syair berisi nasihat dan Tasawuf) 1912, Sullamul Ushul (tentang Ushul Fiqih) 1914, Aiqazum Niam (menyatakan bid'ah berdiri Maulid) 1916, Alfawaidul 'Aliyyah (tentang bid'ahnya melafalkan niat) 1916, Mursyidit Tujjar (pedoman orang berniaga, Syai'r) 1916. Pertimbangan Adat Alam Minangkabau 1918. Dinul Lah (pelajaran agama di Normal School) 1918, Pembua Mata (memberantas nikah muhallil, bercinta buta) 1919, Alifsaah (perihal nikah dan segala hubungannya) 1919, Al-Burhan (Tafsir Juz 'Amma) 1922, Kitabul Rahmah (puasa menurut 4 Madzhab) 1922, Alqaulush Shahih (bantahan atas Ahmadiyah) 1923.

Setelah pulang dari Mesir yakni: Cermin Terus (sanggahan kepada beberapa amal Muhammadiyah) 1928, Annida (menerangkan wajibnya sholat jama'ah) 1929, Pelita 2 jilid (mempertahankan Cermin Terus (1930-1931, Pedoman Guru (membela Muhammadiyah) 1930, Al-Faraid (tuntunan pembagian waris) 1932.Al-Bashir (mempertahankan pelita) 1938, Al-Misbah (memperthankan fatwa mengenai larangan perempuan makruh ikut salat di tanah lapang, berbahasa Arab) 1938, Al-Kawakibud Duriyyah (Bantahan atas ulama Bugis yang mengharmkan khutbah jum'at dalam bahasa Indonesia) 1940, Hanya Allah (membantah kepercayaan Jepang) 1943, Al-Ihsan (membantah majalah Al-Lisan).

Sedangkan mengeni Tafsir Al-Burhan menafsirkan 22 surat al-Qur'an, dengan mengikuti urutan mushaf Uthmni. Tafsir ini termasuk tafsir tertua yang ada di Indonesia. usaha untuk menerjemahkan dan menafsirkan al-Qur'an kedalam Bahasa Indonesia atau bahasa daerah. Tafsir ini ditulis oleh Haji Rosul pada tahun 1922 dan selesai dicetak tahun 1927 di Drukkerij ${ }^{30}$ Fort de Kock, Bukittinggi. ${ }^{31}$

\section{Latar Belakang Penulisan Tafsir}

Didalam pengantar tafsirnya, bahwasanya penulisannya bertujkan agar agama Islam tetap berlandaskan Al-Qur'an sebagai pondasi keagamaanya, dengan cara memahami ayat-ayatnya dengan benar. Memperbaiki ketauhidan kepada Allah swt tegas beliau sampaikan.

Al-Qur'an juga bukan hanya dibaca saja karena jika melihat realiatas masyarakat cukup dengang membaca al-Quran sudah bisa mendalami mengenai al-Qur'an, pada dasarnya antara manusia dan al-Qur'an butuh komunikasi yang lebih jauh sehingga al-

30 Drukkerij merupakan bahasa Belanda yang berarti percetakan. Istilah drukkerijsebagai percetakan sudah dikenal Abdul Karim Amrullah ketika di Mekah yang digunakan oleh Muhammad Majid Kurdi atau mertua dari Shaykh Ahmad Khatib alMinangkabawi. Setelah Majid Kurdi wafat, drukkerij dikelola oleh anaknya yang bernama Hamid Kurdi. Masa Hamid Kurdi inilah kemudian Hamka sebagai anak Abdul Karim Amrullah juga mendapatkan pengalaman sebagai penyusun tulisan dalam bahasa Indonesia di sana.

${ }^{31}$ Helfi, Kritik Abdul Karim Amrullah Terhadap Rabitah di Minangkabau Dalam Tafsir Al-Burhan, Islamica: Jurnal Keislaman, vol. 12, No. 2, (2018), h.482-483. 
Qur'an haruslah dipahami, dimengerti dan diamalkan didalam kehidupan sehari-hari sehingga tujuan dan maksud dari Al-Qur'an dapat dicapai. ${ }^{32}$

Layaknya ulama-ulama zamannya yang multidisipliner, Haji Rasul juga menuangkan waktu untuk menulis Tafsir al-Qur'an sederhana, namun menarik. Dalam kitab ini, Inyiak Rasul menafsirkan 22 surat, mulai dari ad-Dhuha sampai an-Nass. Dalam pengantarnya, beliau mengemukakan bahwa keinginan menulis tafsir ini didasarkan kuliah-kuliah beliau di Surau Jembatan Besi dalam Tafsir al-Qur'an. Meski sederhana, lebih dari itu Tafsir ini telah tersebar dan dibaca hingga luar pulau Sumatera. $^{33}$

\section{Sistematika Penulisan}

Surah-surah yang terkandung dalam tafsir Al-Burhan menafsirkan 22 surah alQur'an dimulai dari Surah Ad-Dhuha yakni surah yang ke 93 yang terdapat dalam susunan mushaf Usmani sampai dengan surah An-Nas surah ke 114 yang terdapat dalam susunan mushaf tersebut

Sebelum memulai penafsiran, Haji Rosul terlebih dahulu menyebutkan sebab turunnya surah, mencantumkan tempat di mana surah itu turun, jumlah ayat dalam satu surah. Kemudian, menerjemahkan ayat demi ayat, mencantumkan perbedaan pendapat para mufassir, memberikan tambahan penafsiran pribadi, menerjemahkan kisah-kisah yang bisa menjadi pelajaran bagi pembaca tafsirnya serta menukil hadis-hadis sebagai keterangan tambahan di dalam tafsirnya. ${ }^{34}$

\section{Penafsiran Abdul Karim Amrullah dalam Surah al-Kafirun}

Surah ini di turunkan menurut ibnu mas'ud, al-Hasan dan Ikrimah diturunkan di Mekkah, sedangkan riwayat lain yaitu perkataan Ibnu Abbas dan Qatadah bahwasanya surat ini diturunkan di Madinah. Surah ini berjumlah 6 ayat, memiliki 20 kalimat dan hurufnya berjumlah $94^{35}$

Allah berfirman dalam Al-Qur'an,



Artinya: "Katakanlah (Muhammad), 'wahai orang-orang kafir!” (Q.S. Al-Kafirun: 1)

Asalnya surah ini diturunkan ketika beberapa putra dari Quraisy yaitu, Al-Haris bin Qiyas, 'As bin wail, Al-Walid bin Mughirah, Al-Aswan bin 'Abdu Ya'guts, Al-Aswad bin Al-Muthalib dan Ummayah bin Khallaf. Mereka datang menjumpai Nabi saw., untuk melakukan negosiasi yang mana menurut mereka akan saling menguntungkan baik kepada Kaum Kafir Quraisy dan Umat Muslim pada masa itu.

Mereka berkata: "Wahai Muhammad, sebaiknya kita berdamai dengan cara ikutilah agama kami (menyembah berhala) agar kami mengikuti agamamu pula. Jadi, antara kita memiliki hubungan satu sama lain. Dengan cara kamu menyembah agama kami selama satu tahun, lalu, kami pula yang akan menyembah agamamu selama setahun.

${ }^{32}$ Abdul Karim Amrullah, Al-Burhan, (Padang: Percetakan Baroe Fort de Kock, 1927), h. 16.

${ }^{33}$ Apria Putra, Chairullah Putra, Bibliografi Karya Ulama Minangkabau Awal Abad XX Dinamika Intelektual Kaum Tua dan Kaum Muda, (Padang: Komunitas Suluah, 2011), h. 86.

\footnotetext{
${ }^{34}$ Abdul Karim Amrullah, Al-Burhan, h.16.

${ }^{35}$ Abdul Karim Amrullah, Al-Burhan, h. 259.
} 
Jika agamamu lebih baik maka kami akan masuk kepada agamu. Sebaliknya, jika agama kami lebih mendatangkan kebaikan, maka kamu pulalah yang ikut agama kami.

Lalu Nabi saw., menjawab: "Aku berlindung kepada Allah dari segala perbuatan yang menyekutukan Allah dengan sesuatu lainnya."

Mereka berkata lagi: " Jika kamu keberatan dengan setahun penyembahan terhadap kami, sembahlah selama setengah tahun dan percayalah kepada agama kami walau hanya setengah-setengah."

Nabi saw. menjawab kembali: Tunggulah! Hingga datang wahyu kepadaku dari tuhanku, lalu turunlah surah Al-Kafirun. Setelah mendapatkan wahyu, Nabi saw., langsung bergegas ke Mesjid untuk menyampaikan wahyu dari Tuhan. Dibacakan oleh Nabi saw. surah ini hingga habis dan diterangkan olehnya, sampai Kaum Kafir Quraisy tidak memiliki harapan lagi.

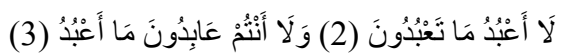

Artinya: “ Tidaklah aku akan menyembah barang yang kamu sembah itu." "Dan tidak pula kamu akan menyembah Tuhan yang aku sembah yakni zaman yang akan datang selama-lamanya tidak berubah.” (Q.S. Al-Kafirun: 2-3)

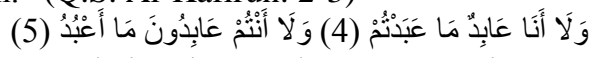

Artinya: "Dan tidak pula aku menyembah sekarang barang yang kamu sembah." "Dan tidak pula kamu sekarang menyembah Tuhan yang aku sembah selama-lamanya." (Q.S. Al-Kafirun: 4-5)

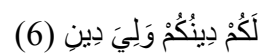

Artinya: "Tetaplah bagi kamu agama kamu, dan bagiku agamaku. Yakni tidak perlu saling gaduh menggaduh adanya." ((Q.S. Al-Kafirun: 6)

Dalam penafsiran surat ini ia mengutip tafsir Al-Qurtubi bahwa surat ini merupakan perintah sebelum adanya peperangan kepada kaum kafir, namun telah di mansukh dengan ayat-ayat yang memperbolehkan berperang melawan orang-orang kafir. Namun tidak berhenti pada satu komentar saja yang melegalkan berperang, karena dalam tafsir al-Qurthubi pula mengatakan tidak ada satupun ayat ini yang telah terhapuskan.

Interpretasi kalimat "bagimu agama kamu" menurut Haji Rasul ialah kamu akan mendapatkan neraka atas agama yang batil yaitu kamu percayai, sedangkan "bagiku agamaku" bagi setiap pemeluk agama Islam akan mendapatkan balasan surga dari Allah. dapat pula di tafsirkan kamu akan mendapatkan balasan atas apa yang kamu percayai dan bagiku pulalah balasan atas apa yang aku percayai, karena menurut Haji Rasul kata 'din' dapat diartikan sebagai balasan.

Yang menjadi diskusi dalam hal ini ialah berperang untuk melawan orang-orang kafir yang terdapat di dalam tafsir al-Qurthubi, karena surat ini telah di mansukh dengan ayat-ayat yang menyuruh untuk berperang melawan orang kafir. Walaupun di dalam tafsir al-Qurthubi sebagaimana yang dikutip oleh Haji Rosul yang berpendapat tidak ada satu pun dalam ayat ini yang telah di mansukh.

\section{Toleransi Menurut Abdul Karim Amrullah}

Abdul Karim Amrullah lalu memberikan komentar mengenai penafsiran kebolehan berperang yang semakin sering diaungkan pada masa hidupnya. Dia menyatakan bahwasanya jika setiap ayat-ayat al-Qur'an yang menyatakan perang kepada orangorang kafir harus di posisikan dengan benar, karena agama Islam tidaklah ada perintah untuk menyuruh berperang, bermusuh-musuhan dengan setiap individual yang ada di

\footnotetext{
${ }^{36}$ Abdul Karim Amrullah, Al-Burhan, h. 264.
} 
muka bumi ini. Yang ada ialah menyerukan berdamai, bersatu, walaupun berbeda agama dan berbeda akan kepercayaan.

Adapun ayat-ayat yang ada perintah untuk berperang yang dimaksud ialah tidaklah terlepas dari konteks yaitu memerangi orang-orang kafir yang selalu menghina, mengancam, melakukan persekusi terhadap orang-orang Islam karena hal tersebut menjadikan sebuah keharusan bagi setiap Muslim untuk memberikan perlawanan walaupun menempuh jalur berperang dengan pengorbanan jiwa bahkan hartanya.

Allah swt., berfirman dalam Q.S. At-Taubah/9: 7 berikut,

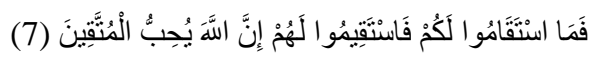

Artinya: "Maka selama mereka berlaku jujur terhadapmu, hendaklah kamu berlaku jujur (pula) terhadap mereka, Allah menyukai orang-orang bertakwa." (Q.S. AtTaubah:7)

Dari ayat di atas tidak ada perintah sama sekali untuk berperang kepada orang-orang kafir, jika di lihat dari terjemahannya umat Muslim haruslah berlaku jujur ataupun baik kepada antar umat beragama selama tidak ada gangguan sesama antar umat beragama, maka sesungguhnya perintah perang harus dibaca sesuai konteksnya. ${ }^{37}$

Ayat selanjutnya, Firman Allah Q.S. Al-Baqarah/2: 194,

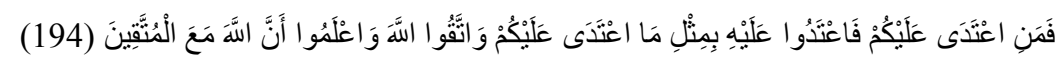

Artinya: "Barangsiapa menyerang kamu, maka seranglah dia setimpal dengan serangannya terhadap kamu. Bertakwalah kepada Allah dan ketahuilah bahwa Allah beserta orang-orang yang bertakwa." (Q.S. Al-Baqarah:194)

Maka jelaslah dari kedua ayat diatas menurut Abdul Karim Amrullah, sudah cukup untuk menjadikan bukti dan juga penjelasan mengenenai keberagaman akan agamaagama. Perbedaan agama dan kepercayaan bukanlah menjadi alasan untuk saling bermusuh-musuhan antara umat Islam dengan penganut agama lainnya, dan tidak pula untul saling berperang satu sama lain. Seruan berperang itu khusus bagi siapa-siapa saja dari non-muslim yang menyakiti serta melampaui batas-batas menghina Islam, mengganggu keamanan bagi umat Muslim. Ajaran agama semata-mata telah menyuruh kita untuk saling berkasih sayang antara sesama hamba yang diciptakan Tuhan,

Allah swt berfirman dalam Q.S. Al-Mumtahanah/60:7

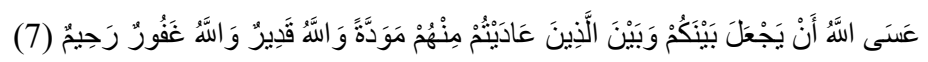

Artinya: Mudah mudahan Allah menimbulkan kasih sayang di antara kamu dengan orang-orang yang pernah kamu musuhi di antara mereka. Allah maha kuasa, dan Allah maha pengampun, maha penyayang. (Q.S. Al-Mumtahanah:7)

Haji Rosul menegaskan bahawa siapa saja mereka yang memperlakukkan Umat Muslim secara baik maka begitu pula dengan Umat Muslim yang harus memperlakukan mereka secara baik pula. Jangan sampai merugikan satu sama lainnya agar menciptakan keharmonisan dengan lainnya. ${ }^{38}$

Allah berfirman dalam Q.S. Al-Mumtahanah/60:8

${ }^{37}$ Abdul Karim Amrullah, Al-Burhan, h. 265.

${ }^{38}$ Abdul Karim Amrullah, Al-Burhan, h.266-267. 




Artinya: "Allah tidak melarang kamu berbuat baik dan berlaku adil terhadap orangorang yang tidak memerangimu dalam urusan agama dan tidak mengusir kamu dari kampung halamanmu. Sesungguhnya Allah mencintai orang-orang yang berlaku adil." (Q.S. Al-Mumtahanah:8)

Oleh sebab itu, Agama Islam menyuruh umatnya untuk berperilaku secara baik hati dengan agama-agama yang lain, karena mereka itu tidaklah menjadi penyebab kerusakan bagi agamamu sekalian. ${ }^{39}$

Berdasarkan hal di atas maka signifikansi dari penelitian ini ialah, adanya perbedaan antara umat beragama merupakan sebuah hukum alam yang telah ada, sehingga sebagai umat Muslim haruslah bersikap sesuai apa yang telah di tuliskan di dalam nas-nas AlQur'an yaitu berperilaku baik dan juga menebarkan kasih sayang kepada setiap makhluk ciptaan Allah yang ada di muka bumi. Perbedaan menciptakan keberagaman yang harus dihormati bukan menebarkan kebencian dan ancaman sehingga toleransi antar umat beragama dapat terwujud sejalan dengan pemahaman yang benar di setiap ajaran-ajaran agama terlebih ajaran Islam.

Tindakan selanjutnya yang perlu dilakukan ialah memberikan pemahaman yang benar tentang ajaran toleransi kepada setiap Muslim, karena jika dilihat saat ini kasus yang terorisme yang mengatasnamakan agama sangat marak terjadi, sehingga butuh usaha yang lebih keras lagi untuk menyebarkan makna-makna perdamaian yang sebenarnya ingin disampaikan oleh Allah, dan untuk penelitian selanjutnya ialah memperbanyak penelitian terhadap kajian tafsir nusantara demi melestarikan khazanah tafsir Indonesia yang pada dasarnya dari dulu hingga sekarang cukup komprehensif.

\section{PENUTUP}

\section{Kesimpulan}

Penafsiran yang dilakukan terhadap surah Al-Kafirun yang berbicara mengenai toleransi antar umat beragama di dalam Tafsir Al-Burhan sangat relevan dengan konteks Indonesia masa kini, sebagaimana dalam pembahasan di atas, tafsir ini tergolong sebagai tafsir yang ditulis sebelum kemerdekaan, yang mana pada saat itu masih ada penjajahan di Indonesia namun hal tersebut tidak menjadi alasan bagi mufassir untuk menafsirkan ayat tersebut dengan perintah perang. Terlebih penekanannya ialah kepada kasih sayang antar umat beragama.

Sehingga metode yang digunakan untuk mendeskripsikan mengenai penafsiran dalam surat al-Kafirun menjawab bagaimana begitu objektifnya Abdul Karim Amrullah dalam melakukan penafsiran, sehingga dalam hal ini perhatian mengenai toleransi antar umat beragama sudah muncul semenjak dahulu.

Dalam tulisan ini masih ada kekurangan yaitu dalam pembacaan penafsiran yang ada di dalam Tafsir Al-Burhan, karena adanya beberapa halaman yang hilang dan juga penulisan yang masih menggunakan bahasa Jawi yang belum baku seperti Bahasa Indonesia saat ini, sehingga dapat menimbulkan kesalahan dalam membaca penafsiran yang dilakukan oleh penulis.

\footnotetext{
${ }^{39}$ Abdul Karim Amrullah, Al-Burhan, h. 268-269.
} 


\section{DAFTAR PUSTAKA}

Amrullah, A. K. ( 1927). Tafsir AL-Burhan. Minangkabau.

Arifin, A. Z., \& Khairudin, M. R. (2019). Ayat Toleransi Dalam Al-Qur'an Perspektif Tafsir Al-Kabir (MafaatihulGhaib). An-Nuha, 196.

ash-Shiddieqy, M. H. (t.thn.). Tafsir al-Qur'anul Majid An-Nur. Semarang: Pustka Rizki Putra.

Asy-Syaukani, I. (2009). Tafsir Fathul Qadir. Jakarta Selatan: Azzam.

ath-Thabarii, A. J. (2009). Tafsir ath-Thabari. Jakarta: Pustaka Azzam.

Bakar, A. (2015). Konsep Toleransidan Kebebasan Beragama. Toleransi: Media Komunikasi Umat Bergama, 130.

Chairullah Putra, A. P. (2011). , Bibliografi Karya Ulama Minangkabau Awal Abad XX Dinamika Intelektual Kaum Tua dan Kaum Muda,. Padang: Komunitas Suluah.

Hamka. ( 1989). Tafsir al-Azhar. Singapura: Pustaka Nasional PTE LTD.

Hamka. (1958). , Ayahku, Riwayat Hidup Dr. H. Abdul KarimAmarullah Dan Perjuangan Kaum Agama Di Sumatera. Jakarta: Widjaya Djakarta.

Hassan, A. (2010). Al-Furqon Tafsir Qur'an. Jakarta : Universitas Al Azhar Indonesia.

Helfi. (2018). Kritik Abdul Karim Amrullah Terhadap Rabitah Di Minangkabau Dalam Tafsir Al-Burhan, . Islamica: Jurnal Keislaman, 482-483.

Huda, M. T., \& Luthfiah. (2018). Toleransi dalam Kitab Tafsir Taisir al-Karim al-Rahman fi Tafsir al-Kalam al-Mannan. Jurnal Qolamuna, 252.

Isma'ill, M. b. (1422). Shahih Al-Bukhori (1 ed.). t.t: Dar Tuk An-Najah.

Mas'udi., M. M. (2019). Toleransi Dalam Islam (Antara Ideal Dan Realita). Al-Hikmah: Jurnal Studi Agama-Agama, 19.

Mursyid, S. (2016). Konsep Toleransi (Al-Samahah) Antar Umat Beragama Perspektif Islam. Jurnal Aqlam Journal Of Islam And Plurality, 50.

Shihab, M. Q. (2002). Tafsir al-Misbah. Jakata: Lentera Hati.

Siswayanti, N. (2016 33-42). Haji Abdul Karim Amrullah Ulama Pembaharu Islam di Minangkabau. Dialog jurnal penlitian dan kajian keagamaan, 33-42.

Siti Suhartinah, D. (2018). Toleransi Antar Umat Beragama Perspektif KH. Ali Mustafa Yaqub. Jurnal Studi Al-Qur'an: Membangun Tradisi Berpikir Qur'an, 66.

Tualeka, M. W. ( 2016). Kajian Kritis Tentang Toleransi Beragama Dalam Islam. $A L$ Hikmah: Jurnal Studi Agama-Agama, 8.

Yasir, M. (2014). Makna Toleransi Dalam Al-Qur'an. Jurnal Ushuluddin , 170. 